\title{
The Structure of Teacher's Directives of the English Lecturers of Muhammadiyah University Semarang
}

\author{
Rr. Dewi Wahyu Mustikasari \\ English Department of Educational Faculty \\ State Islamic Studies Institute (STAIN) Salatiga \\ Jl. Tentara Pelajar No.2 Salatiga, Central Java, Indonesia \\ dewi.w.mustikasari@gmail.com
}

\begin{abstract}
Teacher's directive is an interesting item to discuss since it can be elaborated into command, order, request, and advice. Furthermore, it can be developed that teacher's directive has several structures. The structure of teacher's directives can be classified into three kinds: imperative, interrogative, and declarative. I would like to discuss about the various forms by which directives are realized in the classroom in this study. The subjects of the study were 10 English lecturers of Muhammadiyah University Semarang. The instrument of the study is DCT questionnaires, which is consisted of 10 certain situations. The result shows that most of the subjects of study prefer to produce declarative with 74 utterances $(50 \%)$. Second, they choose imperative with 50 utterances $(34 \%)$. Next, they construct interrogative with 23 utterances (16\%). Declaratives provide powerful directives than the other types. Declaratives gain an explicit expression. Teachers like to use declaratives, since declaratives are understandable. It will minimize the misinterpretation from the students.
\end{abstract}

Keywords: illocutionary act, directives, teacher's directives, the structure of teacher's directives

\begin{abstract}
Abstrak
Instruksi pengajar adalah item yang menarik untuk dibahas karena hal tersebut dapat diuraikan ke dalam bentuk perintah, pemesanan, permintaan, dan saran. Selain itu, intstruksi pengajar memiliki beberapa struktur. Struktur instruksi pengajar dapat diklasifikasikan menjadi tiga jenis: imperatif, interogatif, dan deklaratif . Dalam penelitian ini, peneliti membahas tentang berbagai bentuk instruksi yang dipahami dalam kelas. Subyek penelitian adalah 10 dosen
\end{abstract}


bahasa Inggris dari Universitas Muhammadiyah Semarang. Instrumen penelitian ini adalah kuesioner DCT, yang terdiri dari 10 situasi tertentu . Hasil penelitian menunjukkan bahwa sebagian besar subjek penelitian lebih cenderung untuk menuturkan instruksi deklaratif dengan 74 tuturan (50\%). Kedua, mereka memilih instruksi imperatif dengan 50 tuturan (34 \%). Selanjutnya, mereka memilih instruksi interogatif dengan 23 tuturan (16\%). Ujaran deklaratif memberikan instruksi yang kuat daripada jenis lainnya karena adanya ekspresi eksplisit. Pendidik cenderung menggunakan tuturan deklaratif, karena sifatnya yang mudah dimengerti sehingga meminimalkan salah tafsir pada mahasiswa.

Kata Kunci : Tindak Ilokusi, Instruksi, Petunjuk Pengajar, Struktur Instruksi Guru

\section{Introduction}

Teacher is the center of attraction in the classroom, since he plays an important role in the classroom. Based on Brown (2001: 166-168) there are several kinds of the roles of teacher, namely teacher as controller, teacher as director, teacher as manager, teacher as facilitator, and teacher as resource. Furthermore, no matter what is the teacher role in the classroom, teacher always acts as the central focus of the students' attention. Giving model to the students, it is teacher's duty to provide knowledge, good behavior and attitude. It is in line with the opinion of Holmes (1993: 97) that

"The teacher-pupil relationship is asymmetrical one; the teacher is the older and more knowledgeable than the pupils. The teacher is expected to be in control, to preserve an appropriate social distance from pupils, and to instruct and inform the children: to teach them the body of facts and skills the society values."

Building communication with the students, it could be interesting and tricky at the same time. This situation could happen because the students might 
have different interpretations when teacher produces utterances. Using the spoken meaning, the speaker and the listener can negotiate the meaning, so the understanding of communication is negotiable; depend on the context in which the communication takes place (context dependence) and the shared knowledge of two parties (Eggins, 1994:56-57). As it is negotiable, the oral communication usually uses the un-grammatical form. Teacher communicates with the students not only produces utterances containing grammatical structures and words, but also produces the action. Actions performed by utterances are called speech acts (Yule, 1996:47). There are three kinds of acts: locutionary act, illocutionary act and perlocutionary act.

The three acts perform difference functions. According to Yule (1996:48) locutionary act is a basic act of utterance, or producing a meaningful linguistics expression. The locutionary act is an act of saying something that has a meaning. The second is illocutionary act. It refers to the performing act which not only has a semantic meaning, but also a force of utterance. The last is perlocutionary act. It is an utterance which has an effect to the listener. Meanwhile, Leech (1993:316) claims that the locutionary act as an act (to say something), locutionary act as an act which committed by producing an utterance (like promise, predict, etc), the perlocutionary act as an act produced by an effect of locutionary and illocutionary act.

Searle mentioned on Rani that there are five acts for describing the illocutionary acts: declarations, representatives, expressives, directives, and commissives. Directives are kinds of speech acts that used by the speakers to get or ask someone else to do something. They express what the speaker wants. They can be a command, an order, a request, an advice (Rani, 2004:162). Consider the following examples of directives: 
- Don't go anywhere!

- Open the door!

- Could you lend me some of money?

Michael Halliday (1978:33) is cited by Hudson (1980: 49) mentions that there are three dimensional on which an act of communication: field, mode, tenor. Field is why and about what the purpose and subject matter of the communication. Mode is how the means used in the communication: speech or writing. Tenor is to whom the relations between participants; how the speaker defines how he sees the person with whom he is communicating.

Dealing with the above definition, teacher as the person who controls the class produces directives quite often. Holmes (1993: 97) clarifies that "to regard a great many of teacher's utterances as directive in function." The function of teacher's utterances are directive, because of teacher's utterances consist of command, order, request, and advice. The teacher sometimes does not realize that he makes utterances that the purpose is to get students to do something. Holmes (1993: 98-107) claims that the structure of teacher's directives can be classified into three kinds: imperative, interrogative, and declarative. Meanwhile, Wardhaugh (2006: 284) he clarified that "We can try to classify them by grammatical structure along a number of dimensions, e.g. their clausal type and complexity: active- passive, statement- questionrequest- exclamatory, various combinations of these and so on."

Talking about teacher's directives, Holmes (1993: 98-107) suggests that it needs to consider the social factors to discuss it. The social factors are the participant, the setting, the topic, and the function of communication. It can be elaborated more details. First, the participant deals with two factors such as 
who are speaking and who are they speaking to. Second, the setting or social context of the interaction: where are they speaking? Third, the topic concerns with what is being talked about. Finally yet importantly, the function of communication suggests why they are speaking (Holmes, 2001: 10).

There was a research discussing about the structure of teacher's directives. It was Janet Holmes's research with the title The Structure of Teachers' Directives (1993). The data were collected from the elementary school classroom in New Zealand and Britain. She focused her study on directives, which is restricted in the analysis of utterances intended to elicit a non-verbal response, to get the students to do but not say something. The aim was to describe the various forms by which directives are realized in the classroom. The finding was the directives were divided into three categories: imperative, interrogative, and declarative.

In this study, I would like to discuss about the various forms by which directives are realized in the classroom. Teacher produces directives such as command, order, request, and advice. The purpose of the act is to get the students to do certain activities.

\section{Research methodology}

\section{Subject, instruments, and procedures of data collection}

The subjects of the study were 10 English lecturers of Muhammadiyah University Semarang. I conducted this study in the year of 2010. There were five female and five male lecturers who have various ages and social background. I did not involve as the subject of study during the collection of data. 
The instrument of the study is DCT questionnaires. It consisted of 10 certain situations, it followed by blank spaces on which the subjects asked to give responses for teacher's directives. The English lecturers have to imagine that the speakers in the real life interactions, for example:

\section{Situation 1}

You are preparing to enter the class to teach your students. There are some of the students are seating out side of the class. You want your students to enter the class.

What would you say to get your students enter the class?

Based on the situations described, the subjects were asked to produce directives in the blank spaces provided. The situations were provided by several directives acts such as command, order, request, and advice. As a result, there were 147 utterances. ( I enclosed it in the appendix).

For the procedures, during the data collection, I gave the subject of study the DCT questionnaires. They had to answer the questionnaires in English, since they teach English. It took more than one week to get the data. They answered the questionnaires on the paper sheets.

\section{Data Analysis}

I analyzed the data using the opinion of Holmes (1993: 98-107). She claims that the structure of teacher's directives can be classified into three kinds: imperative, interrogative, and declarative. It can be elaborated more details on table 1 . 
Table 1

Structure of teacher's directives

\begin{tabular}{|c|c|c|}
\hline \multirow[t]{6}{*}{ IMPERATIVES } & Base form of verb & $\begin{array}{l}\text { Speak up. } \\
\text { Put your hands down. }\end{array}$ \\
\hline & You + imperative & $\begin{array}{l}\text { You just see the picture. } \\
\text { You go no with your work. }\end{array}$ \\
\hline & $\begin{array}{l}\text { Present participle form } \\
\text { of verb }\end{array}$ & $\begin{array}{l}\text { Looking at me. } \\
\text { Sitting up straight please. }\end{array}$ \\
\hline & Verb-ellipsis & $\begin{array}{l}\text { Hands up. } \\
\text { Everybody on the mat. }\end{array}$ \\
\hline & Imperative + modifier & $\begin{array}{l}\text { Children looking this way } \\
\text { please. } \\
\text { Turn around please Jo. }\end{array}$ \\
\hline & $\begin{array}{l}\text { Let }+ \text { first } \\
\text { pronoun }\end{array}$ & $\begin{array}{l}\text { Let's finish there. } \\
\text { Let's try. }\end{array}$ \\
\hline \multirow[t]{2}{*}{ INTERROGATIVES } & Modals & $\begin{array}{l}\text { Would you open the window? } \\
\text { David will you read this page } \\
\text { for me? }\end{array}$ \\
\hline & $\begin{array}{l}\text { Non-modal } \\
\text { Interrogative directives }\end{array}$ & $\begin{array}{l}\text { People at the back are you } \\
\text { listening? } \\
\text { Who can I see sitting quietly? }\end{array}$ \\
\hline \multirow[t]{2}{*}{ DECLARATIVES } & Embedded agent & $\begin{array}{l}\text { I want you to draw a picture. } \\
\text { I'd like Arnold's group on the } \\
\text { mat now. }\end{array}$ \\
\hline & Hints & $\begin{array}{l}\text { I can see some nice sitting up. } \\
\text { Helen is sitting nicely. }\end{array}$ \\
\hline
\end{tabular}

Source: Language and Communication

\section{Discussion}

\section{Data Findings}

I found that there 147 utterances. The subject of the study preferred to produce declarative with 74 utterances $(50 \%)$. Second, they chose imperative with 50 utterances (34\%). Next, they constructed interrogative with 23 
utterances (16\%). It can be clarified on table 2. The lecturer as the person who has the superior position produced more casual choice of words to the students. Even though, I found several utterances that constructed with formal choice of words. The classroom setting was provided in the various situations in the questionnaires. The situations made it possible for the subject of the study to produced directives that consist of command, order, request, and advice. The topics of situations talked about the various activities dealing with the teaching and learning process.

Table 2

The Data of Structure of Teacher's Directives

\begin{tabular}{|c|c|c|c|c|}
\hline \multirow[t]{6}{*}{ IMPERATIVES } & Base form of verb & 9 & \multirow[t]{6}{*}{50} & \multirow[t]{6}{*}{$34 \%$} \\
\hline & You + imperative & 9 & & \\
\hline & $\begin{array}{l}\text { Present participle } \\
\text { form of verb }\end{array}$ & 2 & & \\
\hline & Verb-ellipsis & 1 & & \\
\hline & $\begin{array}{l}\text { Imperative } \\
\text { modifier }\end{array}$ & 25 & & \\
\hline & $\begin{array}{l}\text { Let }+ \text { first person } \\
\text { pronoun }\end{array}$ & 4 & & \\
\hline \multirow{2}{*}{$\begin{array}{l}\text { INTERROGATIVE } \\
\mathrm{S}\end{array}$} & Modals & 16 & \multirow[t]{2}{*}{23} & \multirow[t]{2}{*}{$16 \%$} \\
\hline & $\begin{array}{l}\text { Non-modal } \\
\text { Interrogative } \\
\text { directives }\end{array}$ & 7 & & \\
\hline \multirow[t]{2}{*}{ DECLARATIVES } & Embedded agent & 67 & \multirow[t]{2}{*}{74} & \multirow[t]{2}{*}{$50 \%$} \\
\hline & Hints & 7 & & \\
\hline
\end{tabular}

The following are examples of teacher's directives that the subject of the study constructed when responding to the situation in DCT questionnaires.

Situation 1: want your students to enter the class

(1) Hello, guys. Are you coming or not?

(2) Let's enter the class. 
Situation 2: do not want Ahmad to join your class

(3) I'm sorry. As our agreement, you may join the class next week.

(4) Sorry, I can't let you join my class.

Situation 3: want to tell both of them to stop talking and listen to your explanation

(5) Excuse me, would you share your discussion with us? (Implied 'stop talking')

(6) Guys, can you stop talking?

Situation 4: want your student to get the eraser on the administration office

(7) Can somebody do volunteering to take an eraser?

(8) Please go to the administration office and ask an eraser to Mrs. Wati.

Situation 5: want the students to make the assignment and submit the assignment today

(9) I would like you to make the assignment and submit it today!

(10) I want you to do the assignment in class and submit it today before 12.00 .

Situation 6: want the students to answer the question and write the answer on the board

(11) Ahmad, now you answer the question and write it on the board. 
(12) Fika, please write your answer in the board.

Situation 7: want to motivate Heru that he should spend times to study or he will fail

(13) Heru, I need you to study hard to pass this semester.

(14) I don't want to see you fail this semester.

Situation 8: want the students prepare and study the selected chapters for the final-semester test.

(15) Ok, please prepare yourself for your next exam.

(16) Study harder than before, please!

Situation 9: want to tell the students that there is a punishment for them if they broke your rules

(17) For those who discussing and opening the book will be punished.

(18) I will kick you out if you discuss it with your friends.

Situation 10: want to ask the student to submit the answer sheet and force him to leave your class

(19) Ahamad, because you've cheated on the test, I really appreciate if you leave the class.

(20) Bambang, close your book and plaese submit your paper and leave the class (Implied 'stop cheating'). 


\section{Analysis}

The following are the details information about the structure of teacher's directives that is taken from the data:

\section{Imperatives}

The subject of the study liked to use this form, eventhough it took for about $34 \%$ of the data. They constructed this form, since it is relatively explicit. They would like to make the directives clearly and direct to the point of what were they going to say with the students. There were several variants of imperatives according to Holmes. I found they constructed the various variants in completing the questionnaires. The variants are:

a. Base form of verb, e.g. Speak up.

This is the simple form of the imperative. The subject of the study produced this form to make their rules more explicit. The purpose is to minimize the differences of interpretation from the students. Most of them liked to construct negative form rather than positive form. The examples are:

- Don't cheating.

- Don't try to do that because I can anlayze it well.

- Don't forget to study the selected chapters.

- Study hard and good luck!

b. You + imperative, e.g. You just see the picture. 
This form had the same frequency of occurrences from the previous form. The function of "You" is used to address all of students, small group of students and the individual student. The examples are:

- You may leave this class after doing those things (addressing individual student).

- Ahmad, now you answer the question and write it on the board (addressing individual student).

- You can continue your discussion later, after the class finish (addressing small group of students).

- You should prepare for your next final exam (addressing all of students).

- You have to be confident with your own answer (addressing all of students).

c. Present participle form of verb, e.g. looking at me

The subject of the study rarely used this third form. I am not sure what is the reason why they rarely used it. On the contrary, this was a kind of unique form that the New Zealanders produced the imperatives, since Holmes found frequently used by them. She found some difficulties to categorize the utterances, but at the end, she made up her mind to classify these utterances into the form of present participle form of verb. The examples of this form from the data are:

- Discussing and opening the book are disallowed.

- Referring to regulation and agreement.

d. Verb-ellipsis, e.g. everybody on the mat 
This form also seldom used by the subject of the study. The form eliminated the verb and directed to the noun. There is an example of this form:

- Let's up stair for the class.

e. Imperative + modifier, e.g. Children looking this way please.

This form occurred frequently in the data of imperatives. Teacher used the post-modifier such as please and OK after the imperatives as suggested by Holmes, but it is not quite often. On the contrary, I found a large number of the imperatives appeared with the form of pre- modifier. The function of "please" and "ok" is to soften the directives.

It can be clarified by the following examples:

- Study harder than before, please!

- Please go in front of the class.

- Ok, please prepare yourself for your next exam.

- Please listen carefully.

- Please help the class to get the eraser, just ask to the office. Thank you. f. Let + first person pronoun, e.g. Let's finish there.

There was a small amount of this form in the data. I found that the subject of the study used this form to suggest solidarity rather than power. As it can be recognized that teacher has a superior position, they tended to use more casual choice of word to the subordinates. The examples are:

- Let's enter the class.

- Let's do that.. 
- Let's start from Ahmad...

- Let's come to the class, its time to start the class.

Interrogatives

It was surprised that the form of interrogatives to convey directives occurred $16 \%$ from the whole data. It happened this way because the subject of the study liked to mention the directives in an explicit way. The form of interrogatives is less powerful to get the students to the action. There were two types of interrogatives constructed by the subject of the study:

a. Modals, e.g. Would you open the window?

There were a large number of the interrogatives data that is used the form of modals. The subject of the study used "please" to make the directives softer. It tended to get the students' willingness to do the teacher's expectation. It can be described by the following examples:

- Would you please enter the class?

- James, would you please get the eraser on the administration office?

- Brown, would you please answer and write your answer on the board?

- Mas, could you help me to get the eraser in the office, please?

- Can somebody help to find an eraser, please?

b. Non-modal Interrogative directives, e.g. People at the back are you listening?

The subject of the study rarely used the second form of interrogative directives. It was because of this form is not commanding enough to get the students to do something. The examples are:

- Hello, guys. Are you coming or not? 
- Anyone want to answer it?

- Is anyone want to answer question no.2?

- Are you coming?

- Do you want to joint the class or not?

\section{Declaratives}

Declaratives forms were the most frequently occurred in the data of directives. It was occurred 50\% from the whole data. There were two types of declaratives: embedded agent and hints. The previous type was expressed explicitly, and on the other hand, the last type was implicitly.

\section{a. Embedded agent}

e.g. I want you to draw a picture.

Most of the data of declaratives constructed this form. The subject of the study preferred to produce this kind of form, since they would like straight to the point. They liked to be explicit, so that the students would not have different interpretation. The following examples are taken from a large number of the data:

- So, would you listen to someone's speaking first, then later we'll let you speak.

- Any cheating may get consequences.

- You may leave the class now!

- Sorry, I can't let you join my class.

- I will give you $\mathrm{E}$ if you do it.

- I would like to start the lesson. 
- I'd like to explain the lesson and you can talk your problem after I finish my explanation.

- Ricky, would you submit the answer sheet! I don't want any of my students cheating and you can leave the class now.

- I'm sorry. As our agreement, you may join the class next week

b. Hints

The subject of study was rarely used this type, since the form was expressed implicitly. The disadvantage of this type was the students might be confused with the teacher's expressions. It happened because teacher's expression conveyed an implication meaning. It can be shown by the following examples:

- Excuse me, would you share your discussion with us? (Implied 'stop talking')

- Thank you, Dewi. Submit your answer sheet, please! (Implied 'stop cheating')

- Bambang, close your book and plaese submit your paper and leave the class (Implied 'stop cheating')

- Any problem mas? (Implied 'stop talking')

\section{Conclusion}

In conclusion, the result shows that most of the subjects of study prefer to produce declarative with 74 utterances $(50 \%)$. Second, they choose imperative with 50 utterances (34\%). Next, they construct interrogative with 23 utterances (16\%). Declaratives provide powerful directives than the other types. Declaratives gain an explicit expression. Teachers like to use 
declaratives, since declaratives are understandable. It will minimize the misinterpretation from the students.

\section{References}

Brown, Douglas. 2001. Teaching by Principles (Second Edition). New York: Longman, Inc.

Eggins, Suzzane. 1994. An Introduction to Systemic Functional Linguistics. London: Pinter Publisher.

Holmes, Janet. 1993. The Structure of Teachers' Directives: In Richard, Jack and Schmidt, Richard (eds). pp. 89-115.

Holmes, Janet. 2001. An Introduction to Sociolinguistics (Second Edition). New York: Longman.

Hudson, Richard. Anthony. 1980. Sociolinguistics. Cambridge: Cambridge University Press.

Leech, Geoffrey. Oka, M.D.D. (Penerjemah). 1993. Prinsip-prinsip Pragmatik. Jakarta: Universitas Indonesia Press.

Rani, Abdul; Arifin, Bustanul; Martutik. 2004. Analisis Wacana: Sebuah Kajian Bahasa Dalam Pemakaian. Malang: Bayu Media.

Wardraugh, Ronald. 2006. An Introduction to Sociolinguistics (Fifth Edition). London: Blackwell Publisher, Ltd.

Yule, George. 1996. Pragmatics. Oxford: Oxford University Press. 